\title{
Pendidikan Kesehatan pada Kelompok Arisan Wanita dalam Upaya Meningkatkan Kesiapan Wanita dalam Menghadapi Masa Menopause
}

\author{
*Cintika Yorinda Sebtalesy \& Irmawati Mathar \\ STIKES Bhakti Husada Mulia Madiun, Indonesia
}

\begin{abstract}
ABSTRAK
Menopause dikenal sebagai masa berakhirnya menstruasi atau haid. Akibat perubahan dari haid menjadi tidak haid lagi menyebabkan timbulnya berbagai keluhan fisik, baik yang berhubungan dengan organ reproduksinya maupun organ tubuh pada umumnya. Ada baiknya jika seseorang wanita sudah mempersiapkan diri menghadapi masa menopause dengan pengetahuan yang memadai. Kesiapan seorang wanita menghadapi masa menopause akan sangat membantu ia menjalani masa menopause dengan lebih baik. Menurut Pittsburg, sebagian besar wanita menopause di dunia tidak mengetahui tentang menopause. Wanita menopause yang tidak mengetahui tentang menopause hampir 80,9\%. Sebagian besar dari mereka berespon bermacam-macam terhadap datangnya masa ini, yaitu mengalami kecemasan, depresi, stres, mudah marah, daripada wanita yang mengetahui menopause. Berdasar wawancara yang dilakukan peneliti, 10 ibu yang mengalami menopause, 3 ibu mengatakan tidak mengalami perubahan kejiwaan menjelang menopause, 7 ibu mengatakan mengalami perubahan kejiwaan yaitu berupa rasa takut menjadi tua, mudah tersinggung, merasa tidak menarik lagi, takut tidak dapat memenuhi kebutuhan seksual suami, rasa takut suami akan menyeleweng. Pelaksanaan kegiatan pengabdian masyarakat yang digunakan adalah Pendidikan Kesehatan Pada Kelompok Arisan Wanita Dalam Upaya Meningkatkan Kesiapan Wanita Dalam Menghadapi Masa Menopause. Metode yang digunakan adalah terjun langsung memberikan penyuluhan tentang menopause. Dari hasil pengabdian masyarakat yang sudah dilakukan, para wanita antusias dan mengerti tentang menopause dilihat dari hasil post test. Dari hasil yang sudah di dapat tersebut di harapkan para wanita siap untuk menghadapi menopause.
\end{abstract}

Kata kunci : Pendidikan Kesehatan, Kesiapan, Menopause. 


\section{PENDAHULUAN}

Menopause ialah haid terakhir, atau saat terjadinya haid terakhir. Berhentinya haid dapat didahului oleh siklus haid yang lebih panjang, dengan perdarahan yang berkurang. Umur waktu terjadinya menopause dipengaruhi oleh keturunan, kesehatan umum, dan pola kehidupan (Wiknjosastro, 2007).

Menopause dikenal sebagai masa berakhirnya menstruasi atau haid. Akibat perubahan dari haid menjadi tidak haid lagi menyebabkan timbulnya berbagai keluhan fisik, baik yang berhubungan dengan organ reproduksinya maupun organ tubuh pada umumnya (Baziad, 2008). Ada baiknya jika seseorang wanita sudah mempersiapkan diri menghadapi masa menopause dengan pengetahuan yang memadai. Kesiapan seorang wanita menghadapi masa menopause akan sangat membantu ia menjalani masa menopause dengan lebih baik (Kasdu, 2006).

Badan Kesehatan Dunia (WHO) memperkirakan Usia Harapan Hidup orang Indonesia adalah 75 tahun pada tahun 2005 (Siagian, 2003). Meningkatnya usia harapan hidup wanita Indonesia berdampak pada meningkatnya jumlah wanita usia lanjut (lansia) di Indonesia. Pada tahun 2006 angkanya melejit hingga lebih dua kali lipat menjadi 19 juta orang. Pada tahun 2020 diperkirakan jumlah penduduk Indonesia meningkat menjadi 28,8 juta atau 11 persen (Anonim, 2008).

Menurut Pittsburg (1996), sebagian besar wanita menopause di dunia tidak mengetahui tentang menopause. Wanita menopause yang tidak mengetahui tentang menopause hampir 80,9\%. Sebagian besar dari mereka berespon bermacam-macam terhadap datangnya masa ini, yaitu mengalami kecemasan, depresi, stres, mudah marah, daripada wanita yang mengetahui menopause (Manuaba, 2009).

Berdasar wawancara yang dilakukan peneliti, $10 \mathrm{ibu}$ yang mengalami menopause, $3 \mathrm{ibu}$ mengatakan tidak mengalami perubahan kejiwaan menjelang menopause, $7 \mathrm{ibu}$ mengatakan mengalami perubahan kejiwaan yaitu berupa rasa takut menjadi tua, mudah tersinggung, merasa tidak menarik lagi, takut tidak dapat memenuhi kebutuhan seksual suami, rasa takut suami akan menyeleweng.

Dampak menopause yang sering terjadi di masyarakat adalah kecemasan, takut, lekas marah, ingatannya menurun, sulit konsentrasi, gugup, merasa tidak berguna, mudah tersinggung, stress bahkan depresi (Anonim, 2007). Para wanita usia lanjut tersebut juga rentan terhadap penyakit degeneratif misalnya osteoporosis, penyakit jantung koroner, kanker, darah tinggi dan Dimensia tipe alzheimer (Kasdu, 2006).

Gangguan emosi rasa takut menjadi tua dan tidak menarik, sukar tidur atau cepat bangun, mudah tersinggung dan mudah marah, sangat emosional dan spontan, merasa tertekan dan sedih tanpa diketahui sebabnya. Situasi demikian dapat terjadi bila individu belum siap untuk menghadapi menopause (Manuaba, 2006). Perubahan emosional terkadang tidak disadari oleh wanita yang sedang menopause sehingga perlu pendekatan khusus untuk masalah ini. Pendekatan ini bertujuan untuk meyakinkan wanita tersebut atas apa yang sedang diderita (Manuaba, 2006). 
Upaya-upaya yang bisa dilakukan wanita di masa menopause untuk mengurangi berbagai keluhan yang sedang dialaminya adalah dengan meningkatkan cara berfikir positif bahwa terjadinya menopause merupakan suatu proses alamiah yang harus diterima sebagai alur perjalanan hidup manusia, Terapi Sulih Hormon (TSH), olahraga, nutrisi yang cukup terutama dengan mengonsumsi makanan yang mengandung kedelai, gaya hidup sehat dengan tidak merokok dan minum minuman keras, pemeriksaan kesehatan secara berkala, meningkatkan kehidupan religi, menganjurkan para wanita menopause untuk mengikuti posyandu lansia, seminar dan ceramah tentang menopause (Kasdu, 2006).

Ibu menopause yang berpengetahuan baik memiliki tingkat kecemasan yang rendah dalam menghadapi masa menopause. Seperti berolahraga secara teratur, berkonsultasi dengan dokter tentang masalahkesehatannya, mengkonsumsi makanan bergizi, menghindari merokok dan minuman beralkohol (Ahmadi, 2007).

Sedangkan ibu yang berpengetahuan kurang cenderung memiliki tingkat kecemasan yang tinggi dalam menghadapi masa menopause seperti tidak berolahraga secara teratur, tidak mengkonsumsi makanan yang bergizi, mengandung bahan pengawet, pewarna dan tinggi kolesterol, tidak melakukan aktivitas apapun dan menghabiskan waktunya untuk tidur, dll (Kasdu, 2006).

Berdasarkan permasalahan yang ada, maka kami ingin mengadakan pendidikan kesehatan mengenai upaya menghadapi menopause di dukuh Ngrobyong.

\section{METODE}

Pelaksanaan kegiatan pengabdian masyarakat yang digunakan adalah Pendidikan Kesehatan Pada Kelompok Arisan Wanita Dalam Upaya Meningkatkan Kesiapan Wanita Dalam Menghadapi Masa Menopause. Metode yang di gunakan adalah terjun langsung memberikan Pendidikan Kesehatan Pada Kelompok Arisan Wanita Dalam Upaya Meningkatkan Kesiapan Wanita Dalam Menghadapi Masa Menopause Dukuh Ngrobyong Kecamatan Geger Kabupaten Madiun.

\section{Strategi}

a. Jumlah dosen berjumlah 2 orang dan mahasiswa 4 orang.

b. Tim pengusul melakukan pendataan pada kelompok arisan wanita Ngrobyong dan mencari informasi mengenai masalah pra menopause.

c. Tim pengusul meminta izin kepada ketua kelompok arisan wanita Ngrobyong untuk mengadakan pendidikan kesehatan.

d. Tim pengusul bersama ketua kelompok menetapkan jadwal untuk pengadaan pendidikan kesehatan.

e. Tim pengusul memberikan materi pendidikan kesehatan pada saat acara arisan diadakan.

f. Tim pengusul melakukan evaluasi kepada kelompok arisan wanita Ngrobyong. 


\section{Metode}

a. Melakukan pengkajian dengan mencari informasi permasalahan wanita usia mendekati menopause.

b. Memberikan Penyuluhan Kesiapan Wanita Dalam Menghadapi Menopause.

\section{HASIL DAN PEMBAHASAN}

\section{Pembentukan Posyandu Lansia}

Pelaksanaan kegiatan pengabdian masyarakat dilakukan pada tanggal 15 Januari 2018 di Rumah Ketua Kelompok Arisan Dukuh Ngrobyong Desa Purworejo Kecamatan Geger, Kab.Madiun. Kegiatan pengabdian masyarakat dihadiri oleh 30 warga. Jenis kegiatannya meliputi:

a. Memberikan penjelasan tentang pengertian menopause

b. Memberikan penjelasan tentang tanda dan gejala menopause

c. Memberikan penjelasan tentang macam-macam menopause

d. Memberikan penjelasan tentang faktor-faktor yang mempengaruhi menopause

e. Memberikan penjelasan tentang tahap-tahap menopause

f. Memberikan penjelasan tentang perubahan masa menopause

g. Memberikan penjelasan tentang permasalahan menopause.

Hasil pelaksanaan kegiatan pengabdian masyarakat berjalan dengan lancar, para wanita terlihat antusias, pengetahuan wanita bertambah mengenai menopause.

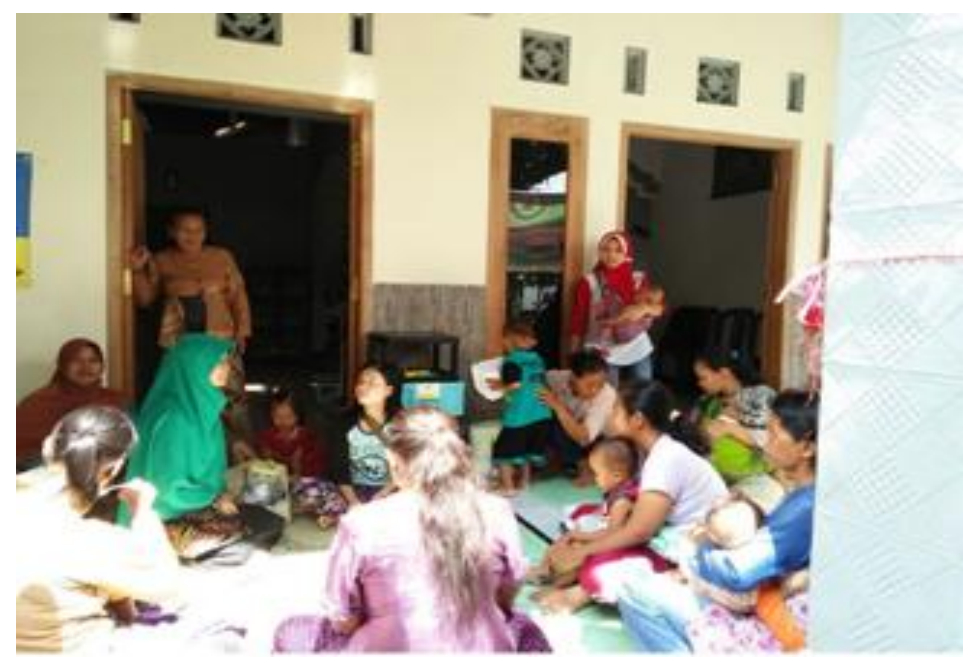

Gambar 1

Saat Melakukan Pendidikan Kesehatan 


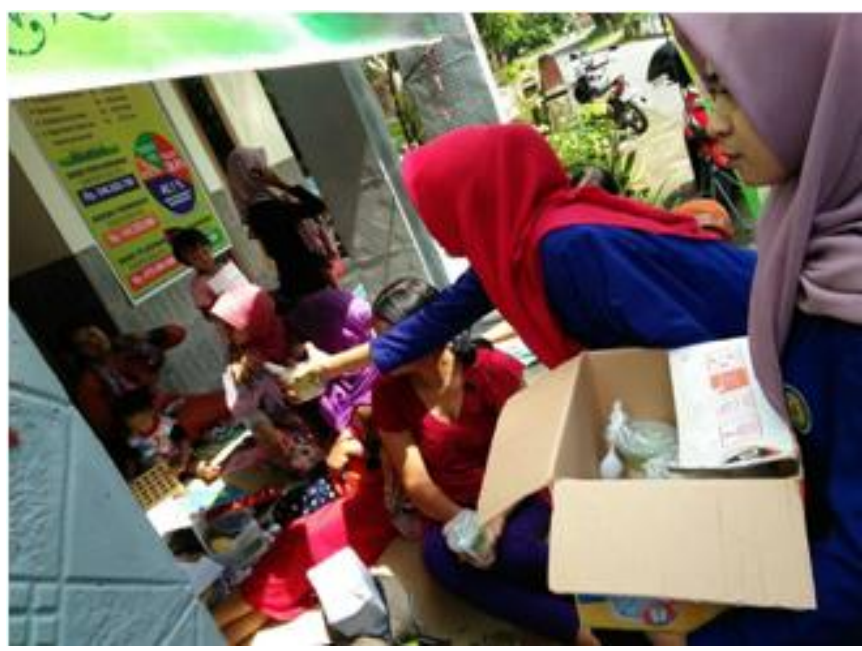

Gambar 2

Saat Memberikan Reward Kepada Penanya Dibantu oleh Mahasiswa

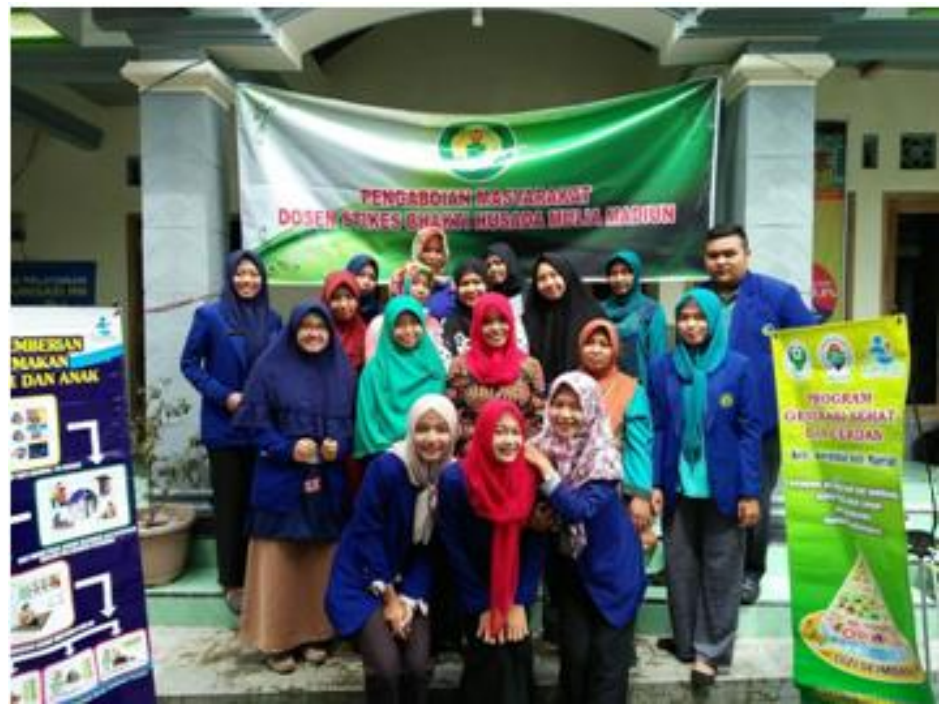

Gambar 3

Saat Selesai Kegiatan Pendidikan Kesehatan

Beberapa faktor pendukung kegiatan ini antara lain : 1. Para peserta memiliki kemauan yang besar untuk mendapatkan informasi dan pengetahuan mengenai menopause sebagai bekal saat menghadapi menopause. 2. Kegiatan pendidikan kesehatan ini sangat didukung oleh pihak desa, baik secara spontan maupun di belakang layar berpartisipasi secara aktif dalam pelaksanaan pendidikan kesehatan tentang menopause. 3. Antusias ibu-ibu arisan juga dituunjukkan dengan banyaknya pertanyaan saat acara berlangsung, bagi memberikan pertanyaan, panitia kegiatan memberikan apresiasi dengan memberikan reward berupa makanan. 
Kendala yang dihadapi dalam kegiatan ini yaitu keterbatasan dalam fasilitas pendukung untuk melakukan presentasi diantaranya tidak ada tayangan gambar/ slide dari LCD proyektor karena keterbatasan waktu dan kondisi ibuibu yang membawa putra putrinya sehingga fokus peserta belum terpusat pada narasumber.

Sebelum dilakukan pendidikan kesehatan, terdapat 70\% ibu-ibu yang belum memiliki pengetahuan yang cukup mengenai menopause dan berdasarkan hasil wawancara awal dengan ketua PKK, di Desa Purworejo, belum ada program untuk ibu menopause. Setelah dilakukan pendidikan kesehatan ini, 90\% ibu-ibu sudah memiliki pengetahuan yang cukup mengenai menopause dilihat dari hasil post tes yang dibagikan setelah ceramah. Selain itu, ketua PKK dapat mengetahui pengetahuan warganya tentang menopause sehingga akan melahirkan program baru yaitu pembinaan pengetahuan bagi wanita yang telah menopause.

\section{SIMPULAN}

Dari pertanyaan yang di tanyakan oleh peserta dan cara peserta mengulang materi dengan benar, memberikan bukti para peserta mampu memahami apa yang disampaikan oleh pemateri. Kegiatan ini dilakukan sebagai upaya meningkatkan kesiapan wanita dalam menghadapi masa menopause. Peserta dan ketua PKK dapat mengetahui seberapa jauh pengetahuannya tentang menopause sehingga akan melahirkan program baru yaitu pembinaan pengetahuan bagi wanita yang telah menopause.

\section{UCAPAN TERIMA KASIH}

Penulis mengucapkan terima kasih kepada STIKES Bhakti Husada Mulia yang telah mendukung terlaksananya kegiatan pendidikan kesehatan ini dengan cara memberikan izin. Penulis juga mengucapkan terima kasih kepada kelompok arisan wanita Desa Purworejo Kecamatan Geger Kabupaten Madiun, yang telah mengizinkan dan memberi dukungan kegiatan pengabdian ini.

\section{DAFTAR PUSTAKA}

Ahmadi, A. (2007). Pengantar Ilmu Perilaku Kesehatan. Jakarta: PT. Rineka Cipta.

Baziad, M. A. (2008). Menopause dan Andropause. Jakarta: Yayasan Bina Pustaka.

Kasdu, D. (2006). Kiat Sehat dan Bahagia di Usia Menopause. Jakarta: Puspa Swara.

Manuaba, I. A., \& Suryaputra, S. K. (2006). Buku Ajar Ginekologi. Jakarta: EGC.

Sebtalesy, C. Y., \& Mathar, I. (2019). The Role of Husband in Menopause Against the Wife's Anxiety Level Facing Menopause in Purworejo Village, Geger District, Madiun Regency. Jurnal Midpro, 102-110.

Wiknjosastro, H. (2006). Ilmu Bedah Kebidanan. Jakarta: Yayasan Bina Pustaka Sarwono Prawirohardjo. 